\title{
PEREMAJAAN OPTIMAL TANAMAN KARET DI PT. PERKEBUNAN NUSANTARA IX (ANALISIS SIMULASI PADA KEBUN GETAS)
}

\author{
Optimum Replanting for Rubber in PT.Perkebunan Nusantara IX \\ (Simulation Analysis at Getas Estate)
}

\author{
Titik WIDYASARI ${ }^{1,2)}$, Slamet HARTONO ${ }^{2)}$ dan IRHAM ${ }^{2)}$ \\ ${ }^{1)}$ Balai Penelitian Getas, Pusat Penelitian Karet \\ Jl.Pattimura km 6, Salatiga \\ Email: titikwidyasari@gmail.com
}

\author{
${ }^{2)}$ Jurusan Sosial Ekonomi, Fakultas Pertanian, Universitas Gadjah Mada, \\ Jl. Flora 1, Bulaksumur, Yogyakarta, \\ Email: hartono.slamet@yahoo.com, irhamsec2000@yahoo.com
}

Diterima : 2 Maret 2015 / Direvisi : 13 April 2015 / Disetujui : 20 Mei 2015

\begin{abstract}
Rubber replanting used to carried out before reaching 30 years because of inappropriate technical consideration without a completed financial analysis. The research aimed to determine the right time and replanting pattern and also to analyze the sensitivity to changes in cost increases and price declines. The sample was taken by purposive, located in Getas Estate, PT Perkebunan Nusantara IX, Semarang regency, Central Java, using profit maximization concept. The results showed that the optimum period to replant rubber should be at the $25^{\text {th }}$ year and the optimal pattern was $4 \%$ of the area of rubber plantations. The same results was also shown when had been done with 5-10\% price reduction and $5-10 \%$ cost increase simultaneously. Although has the similar result, but it had different value of $M N R$ and ANR, that MNR and ANR values were lower due to falling prices and rising costs. The company should replant rubber at the optimum period, otherwise it will not reach the Anticipated Highest Average Net Revenue (ANR). However, these conditions depended on the productivity of rubber, rubber selling prices and costs. Companies should replant the rubber plantations according to appropriate technical and financial considerations, so that sustainable and balanced plantation can be achieved.
\end{abstract}

Keywords: Optimum replanting, rubber, profit maximization

\section{Abstrak}

Peremajaan tanaman karet umumnya dilakukan sebelum mencapai 30 tahun karena pertimbangan teknis yang tidak sesuai, dan belum dilengkapi analisis finansial yang tepat. Penelitian bertujuan untuk memperoleh saat dan pola peremajaan optimal tanaman karet serta melihat responnya terhadap perubahan kenaikan biaya dan penurunan harga. Pengambilan sampel dilakukan secara purposive, dilakukan di Kebun Getas, PT. Perkebunan Nusantara IX, Kabupaten Semarang, Jawa Tengah, dengan menggunakan konsep maksimalisasi keuntungan. Hasil penelitian menunjukkan bahwa saat optimal peremajaan tanaman karet adalah saat umur 25 tahun, dan pola optimal peremajaan adalah 4\% dari luasan kebun karet. Saat optimal dan pola optimal peremajaan juga tetap, saat dilakukan perubahan kenaikan biaya $5-10 \%$ dan penurunan harga $5-10 \%$ secara simultan. Meskipun saat dan pola peremajaan optimalnya terjadi pada saat yang sama, namun memiliki perbedaan nilai MNR dan ANR yang semakin rendah seiring dengan turunnya harga dan naiknya biaya. Perusahaan sebaiknya melakukan peremajaan di saat optimal, jika melakukan peremajaan sebelum saat optimal maka belum mencapai keuntungan rata-rata tahunan yang maksimum. Namun kondisi tersebut, tergantung produktivitas tanaman karet, harga jual karet dan biayanya. Perusahaan sebaiknya meremajakan kebun karet sesuai pertimbangan teknis dan finansial, sehingga kebun dapat berlanjut dengan seimbang.

Kata kunci : Peremajaan optimal, tanaman karet, maksimalisasi keuntungan

\section{PENDAHULUAN}

Kebun Getas merupakan salah satu kebun milik PT. Perkebunan Nusantara IX berlokasi di tiga kecamatan, yaitu Kecamatan Pabelan, Tuntang, dan Beringin, Kabupaten Semarang, Propinsi Jawa Tengah 
yang memiliki tanaman karet seluas 1.602 Ha. Pada tahun 2013 komposisi tanaman karet di Kebun Getas meliputi : Tanaman Tahun Ini (TTI), Tanaman Belum Menghasilkan (TBM) dan Tanaman Menghasilkan (TM) yang ditampilkan dalam Gambar 1.

Bagi tanaman karet (hevea brasiliensis Muell.Arg), produktivitas tanaman menjadi tolak ukur potensi ekonomi kebun atau menentukan tingkat profitabilitas perusahaan. Oleh karena itu, salah satu usaha yang dapat dilakukan untuk meningkatkan produktivitas tanaman adalah dengan melakukan peremajaan tanaman secara teratur dan tepat. Peremajaan tanaman karet dilakukan dengan maksud mengganti tanaman tua dengan tanaman baru yang memiliki produktivitas tinggi, kualitas tinggi dan secara ekonomi jauh lebih menguntungkan daripada tanaman awal. Menurut Rajino, (1984), pengertian peremajaan ada dua, yaitu : replanting dilakukan di atas lahan bekas tanaman lama yang serupa sedangkan new replanting dilakukan di atas lahan baru bagi tanaman tersebut.

Tanaman karet memiliki masa produktif 25-30 tahun. Kondisi ini memerlukan reinvestasi pada tanaman karet, dimana peremajaan merupakan kunci yang penting. Dalam sistem konvensional berupa cara tanam monokultur, sejumlah modal tetap selama 5-8 tahun merupakan masa tidak produktif, dimana tidak ada pemasukan (zero income). Hal tersebut dapat ditutup dengan pemasukan selama masa selanjutnya 25-30 tahun sebagai masa produktif. Tingkat bunga diperlakukan sebagai elemen yang penting dalam analisis discount cash flow (Sammarappuli et al., 1997).

Tujuan peremajaan menurut Iskandar (1984) adalah untuk mencapai efisiensi sebesar mungkin, sehingga akan memperoleh keuntungan yang makin besar. Sedangkan keuntungan mengadakan peremajaan adalah berupa kesempatan untuk menggunakan :

a) Bahan tanam baru berupa klon unggul hasil pemuliaan dan seleksi akhir,

b) Hasil penelitian terbaru dalam bidang bercocok tanam,

c) Hasil penelitian dalam bidang manajemen/pengelolaan, sehingga penempatan (lokasi) pabrik, pembuatan jalan, dan sebagainya dapat diatur sedemikian rupa hingga menghemat dalam penggunaan tenaga dan biaya.

Secara teknik, Wargadipura (1978) berpendapat bahwa tanaman karet yang berumur 30 tahun selain produksinya rendah, juga keadaan kulit dan persediaan cadangan kulitnya sudah jauh berkurang. Secara ekonomi, Sutardi (1973) berpendapat, walaupun tanaman karet sampai umur 30 tahun, masih memberikan keuntungan, namun tidak optimal lagi. Semakin tua umur tanaman akan menyebabkan rendahnya produktivitas

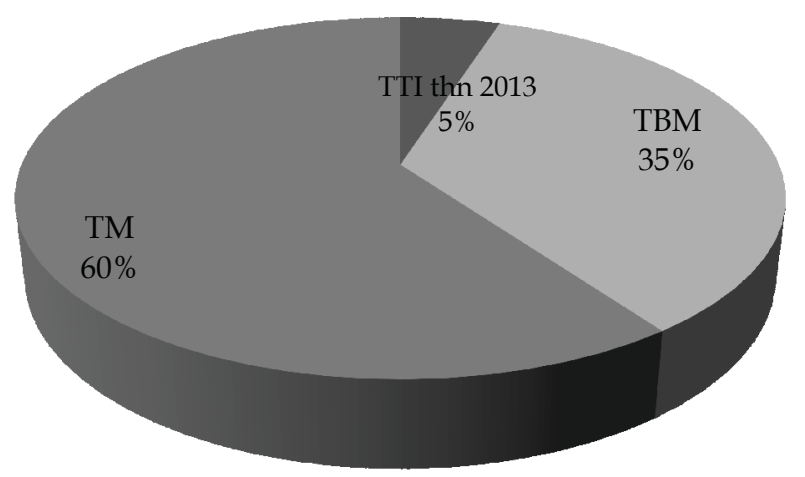

Sumber (source): PTPN IX, 2014

Gambar 1. Komposisi luas tanaman karet di Kebun Getas

Figure 1. The composition of rubber planting area in the Getas Estate 
tanaman karet sehingga mengakibatkan penurunan keuntungan perusahaan. Hal ini telah terjadi di perkebunan besar, dimana produksi kebun jauh dari yang diprediksikan, dan bahkan cenderung meremajakan tanaman karet sebelum mencapai umur tanam 30 tahun. Oleh karena itu, bagi perkebunan sangat penting melakukan peremajaan tanaman secara tepat.

Pada kenyataannya, banyak kendala yang dihadapi dalam pelaksanaan peremajaan, antara lain tingginya biaya peremajaan, kerugian akibat hilangnya produksi selama masa peremajaan (tanaman karet secara normal mulai berproduksi pada saat umur 5 tahun), harga jual karet yang fluktuatif (saat harga tinggi tentunya sayang untuk meremajakan tanaman), dan kendala lainnya. Penentuan suatu kebun diremajakan atau tidak, ditentukan berdasarkan beberapa kriteria, yaitu produksi per hektar, umur tanaman, cadangan dan kondisi kulit, serta keadaan tanaman secara keseluruhan. Faris (1960) berpendapat bahwa penentuan kapan peremajaan tanaman karet dilakukan dipengaruhi oleh nilai uang itu sendiri, dimana uang yang diinvestasikan sekarang akan berbeda nilainya pada waktu yang akan datang sebagai akibat adanya faktor bunga. Mesike dan Sagay (2010) menyatakan bahwa peremajaan perkebunan karet di Nigeria bervariasi karena faktorfaktor seperti harga input dan output, perubahan tingkat diskonto, pajak penghasilan, dan kemampuan manajerial pemilik kebun.

Berdasarkan uraian di atas, maka permasalahan yang akan diteliti adalah kapan saat dan pola yang optimal untuk peremajaan tanaman karet di Kebun Getas, dan bagaimana respon peremajaan tanaman karet terhadap perubahan biaya dan harga jualnya secara simultan. Penelitian ini diharapkan dapat memberikan informasi kepada perusahaan dan pihak lain yang berkaitan dengan tanaman karet mengenai kapan peremajaan yang optimal dari segi waktu dan pola nya, serta responnya terhadap kenaikan biaya dan penurunan harga jual, sehingga dapat dijadikan pedoman peremajaan dari segi finansial, tidak hanya sekedar pertimbangan teknis lapangan yang umumnya dilakukan.

\section{BAHAN DAN METODE}

Penelitian dilakukan dengan penentuan sampel kebun secara 'purposive' yang dilakukan di Kebun Getas, PT Perkebunan Nusantara IX, Semarang, Jawa Tengah. Data primer diperoleh dari Kebun Getas, PT Perkebunan Nusantara IX (persero), sedangkan data sekunder dari Pusat Penelitian Karet, IRSG (International Rubber Statistic Group), Bank Indonesia, BPS (Biro Pusat Statistik), dan instansi yang terkait. Penelitian dilakukan pada tahun 2014.

Data cross section dikumpulkan berupa data produksi tanaman karet umur 1-30 tahun (satu siklus tanam karet), sedangkan data lainnya merupakan data tahun 2013. Data yang diamati dalam satuan per hektar per tahun, meliputi produktivitas tanaman, biaya investasi, biaya produksi (biaya tanaman menghasilkan, biaya panen, dan biaya pengolahan), harga jual karet tingkat kebun, nilai tukar US\$ terhadap rupiah dan suku bunga.

Analisis peremajaan optimal tanaman karet di Kebun Getas meliputi beberapa hal sebagai berikut:

1. Analisis peremajaan optimal tanaman karet

Ada tiga konsep yang disampaikan oleh Faris (1960) perihal penentuan saat optimum peremajaan menurut umur ekonomisnya, yaitu:

a. Produksi jangka pendek dengan penerimaan yang diwujudkan dengan cara penjualan aset, yaitu suatu usaha jangka pendek dimana penerimaan diperoleh dengan menjual asetnya. Intinya, memaksimumkan penerimaan bersih sehingga peremajaan optimum terjadi saat tambahan penerimaan bersih (marjinal net revenue) sama dengan penerimaan bersih rata-rata (average net revenue).

b. Produksi jangka panjang dengan penerimaan yang diwujudkan dengan cara penjualan aset, yaitu suatu usaha jangka panjang dimana penerimaan usaha diperoleh dengan menjual aset di akhir pengusahaan aset tersebut. 
Contoh : tanaman jati. Penerimaan penjualan diterima saat tanaman jati ditebang. Prinsip peremajaan optimum pada konsep kedua ini adalah saat tambahan penerimaan bersih (marginal nett revenue) dari kegiatan saat ini adalah sama dengan amortisasi tertinggi dari pendapatan bersih yang diantispasi dari kegiatan selanjutnya (ANR atau anticipated of nett revenue).

c. Produksi jangka panjang yang diwujudkan dengan cara penjualan sepanjang hidup aset, yaitu suatu usaha jangka panjang dimana penerimaan diperoleh dari produksi sepanjang hidup aset. Contoh : kopi, karet, teh, kelapa sawit dan kakao. Pada pengusahaan tanaman tersebut, penerimaan diperoleh saat tanaman mulai menghasilkan sampai tanaman tersebut secara teknis (agronomis) tidak mampu menghasilkan lagi. Prinsip peremajaan optimum pada konsep ini adalah dimana penerimaan bersih (nett revenue) diterima dari penerimaan. Namun ada hal yang berbeda dengan konsep pertama, dan kedua yaitu dalam hal metode penanganan tanaman dan biaya tanaman. Penerimaan bersih tahunan (the annual nett revenue) merupakan juga tambahan penerimaan bersih (marginal nett revenue) sehingga saat peremajaan optimum terjadi pada saat keuntungan bersih per tahun sama dengan amortisasi dari nilai kini keuntungan total selama satu masa pengusahaan (ANR atau amortisasi of nettrevenue).

Konsep yang sesuai untuk penelitian ini adalah konsep ketiga, karena tanaman karet merupakan tanaman tahunan yang memiliki siklus hidup yang panjang dan penerimaan diperoleh pada saat tanaman mulai menghasilkan. Kondisi optimal peremajaan akan tercapai jika pendapatan bersih marjinal (Marginal Net Revenue) pada suatu saat sama dengan taksiran penerimaan bersih rata-rata tertinggi (Anticipated Highest Average Net Revenue) sampai pengusahaan tahun berikutnya (Faris, 1960). Secara matematis dapat dituliskan sebagai berikut:

MNR = ANR tertinggi

Adapun rumus $\mathrm{MNR}=\mathrm{NR}_{\mathrm{n}}-\mathrm{NR}_{\mathrm{n}-1}$

Keterangan :
MNR : Marginal Net Revenue (Penerimaan Bersih Marjinal)

$\mathrm{NR}_{\mathrm{n}} \quad$ : Net Revenue pada tahun ke-n

$\mathrm{NR}_{\mathrm{n}-1}$ :Net Revenue pada tahun $\mathrm{ke}^{-}{ }_{\mathrm{n}-1}$ Sedangkan ANR diperoleh dengan rumus

$$
A N R=\frac{P V(1+i)^{n}(i)}{(1+i)^{n}-1}
$$

Keterangan :

ANR : amortisasi dari nilai kini penerimaan bersih

PV : nilai kini dari penerimaan bersih

n : lama periode pengusahaan

I : tingkat bunga

Peremajaan optimal dilakukan saat keuntungan rata-rata maksimum sama dengan nilai kini dari keuntungan per satuan waktu (Dillon, 1968). Sedangkan saat optimal peremajaan dipilih saat umur tanaman (n) dimana nilai penerimaan bersih rata-rata mencapai nilai maksimum (ANR*). Jika penerimaan bersih yang diperoleh dari produksi sekarang sudah menyamai penerimaan bersih rata-rata tertinggi dari produksi pengganti, maka program peremajaan akan dilaksanakan. Pada saat optimal tersebut, pola yang dapat diterapkan adalah dengan menggunakan rumus :

Pola peremajaan $=\frac{1}{n} \times L \times 100 \%$

Keterangan :

$\mathrm{n}$ : umur ekonomis, umur tanaman saat tercapainya saat optimum peremajaan

$\mathrm{L}:$ luas areal tanaman (Ha)

Peremajaan optimal adalah peremajaan yang dilakukan pada saat umur ekonomi mencapai keuntungan rata-rata tahunan maksimum dan luas peremajaannya seluas tanaman dibagi umur ekonomi. Umur ekonomi adalah umur pada saat tanaman memberikan keuntungan rata-rata tahunan yang maksimum sedangkan luas optimum adalah ratio antara luas tanaman dengan umur ekonomi. Adapun kriteria peremajaan adalah batas umur tanaman dimana pada saat tersebut nilai kini revenue netto marginal sama dengan revenue netto rata-rata yang maksimal. Pada umur-umur tersebut tanaman perlu diremajakan supaya diperoleh keuntungan yang tinggi. Letak saat optimal peremajaan akan tergantung pada aset dari revenue netto marginal, yang dipengaruhi oleh produksi dan biaya per hektar per tahun. Oleh karena itu, sifat 
biologis, klon dan cara-cara kultur teknis mempengaruhi saat optimal peremajaan (Sutardi, 1973).

\section{Teknik analisis sensitivitas}

Teknik analisis sensitivitas dilakukan untuk melihat respon peremajaan optimal tanaman karet terhadap beberapa perubahan seperti kenaikan biaya dan penurunan harga. Menurut Gittinger (1986), meneliti kembali suatu analisis untuk dapat melihat pengaruh-pengaruh yang akan terjadi akibat keadaan yang berubah-ubah disebut sebagai analisis sensitivitas. Proyek pertanian pada umumnya sensitif berubahubah akibat empat masalah utama, yaitu : harga, keterlambatan pelaksanaan, kenaikan biaya, dan hasil. Analisis sensitivitas bertujuan untuk melihat apa yang akan terjadi dengan hasil analisis proyek jika ada suatu kesalahan atau penambahan dalam dasar-dasar perhitungan biaya atau benefit (Kadariah et al., 1999).

\section{HASIL DAN PEMBAHASAN}

1. Luas areal kebun karet di Kebun Getas

Kebun Getas memiliki TBM dan TM seluas $1.520 \mathrm{Ha}$, dan penggunaan klon tanaman karet yang bervariasi, tampak dalam Tabel 1.

Kebun Getas sudah menggunakan beberapa klon anjuran Puslit Karet tahun 2010-2014, yaitu BPM 24, PB 260, PB 340,
BPM 1, IRR 118, dan RRIC 100 diharapkan dengan penggunaan klon tersebut dapat memperoleh produktivitas yang lebih tinggi dari sebelumnya dengan pemeliharaan yang sesuai anjuran.

\section{Produktivitas tanaman karet}

Produktivitas tanaman karet di Kebun Getas tahun 2006-2013 berfluktuasi, seperti tampak dalam Gambar 2 . Produktivitas terendah di tahun 2009, dan tertinggi di tahun 2012 sebesar 1.768 $\mathrm{kg} / \mathrm{ha} / \mathrm{th}$.

Tanaman karet di Kebun Getas mulai menghasilkan pada tahun ke-6, produktivitas tertinggi saat tanaman mencapai umur 15 tahun (PTPN IX, 2013a). Data produktivitas kebun Getas yang tersedia adalah tahun 1999-2013, sehingga dengan pendekatan simulasi, dapat diperoleh proyeksi produktivitas Kebun Getas selama satu siklus tanam (umur 6-30 tahun) ditampilkan dalam Gambar 3.

\section{Biaya investasi}

Biaya investasi merupakan biaya yang dikeluarkan sejak tahun ke-0 (Tanaman Tahun Ini/ TTI) hingga tahun ke-5 (TBM5), yang meliputi : biaya tanaman belum menghasilkan (TBM) dan biaya umum. Total biaya investasi sebesar Rp 71.549.000,-/Ha, dengan distribusi biaya tercantum dalam Gambar 4. Biaya terbesar terjadi pada TBM1 (32\%) terutama untuk biaya pemupukan TBM dan biaya umum.

Tabel 1. Luas dan klon tanaman karet di Kebun Getas

Table 1. Rubber plant area and the clones in Getas Estate

\begin{tabular}{|c|c|}
\hline \multicolumn{2}{|c|}{$\begin{array}{l}\text { Tanaman Belum Menghasilkan (TBM) } \\
\text { Immature plant }\end{array}$} \\
\hline Luas (ha) & 557,72 \\
\hline Klon & IRR 44, PB 260, PB 340, BPM 1, IRR 118, RRIC 100 \\
\hline \multicolumn{2}{|c|}{$\begin{array}{l}\text { Tanaman Menghasilkan (TM) } \\
\text { Mature plant }\end{array}$} \\
\hline $\begin{array}{l}\text { Luas (ha) } \\
\text { Klon }\end{array}$ & $\begin{array}{l}\text { 960,78 } \\
\text { PR 300, PR 303, GT1,BPM 1, BPM 24, RRIC 100, IRR } \\
\text { 39, PB } 260\end{array}$ \\
\hline
\end{tabular}

Sumber (source): PTPN IX, 2013b 
Widyasari, Hartono dan Irham

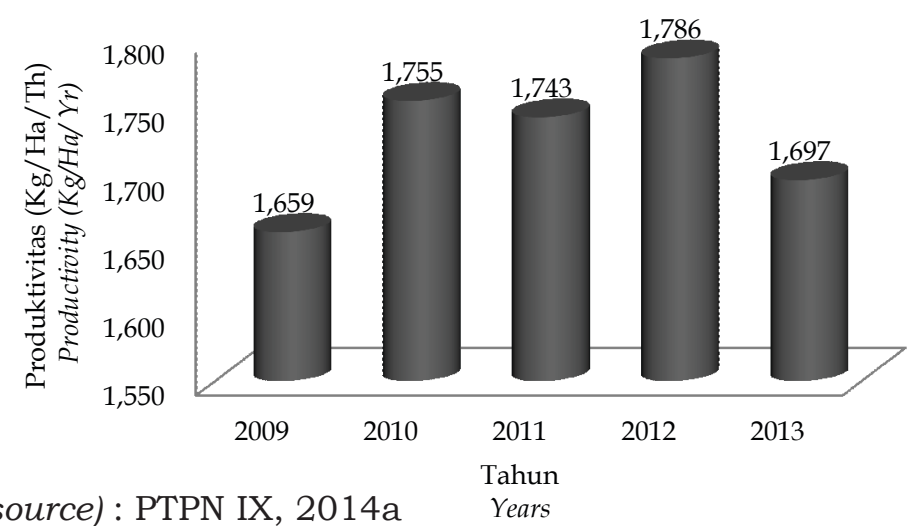

Sumber (source) : PTPN IX, 2014a Years

Gambar 2. Produktivitas tanaman karet di Kebun Getas, 2009-2013

Figure 2. Rubber productivity in Getas Estate, 2009-2013

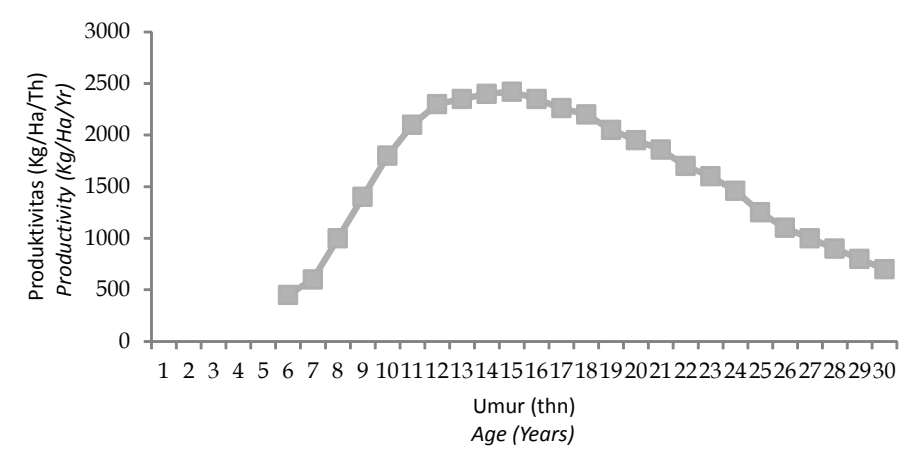

Sumber (source): PTPN IX, 2013a (data sekunder yang diolah).

Gambar 3. Produktivitas tanaman karet dalam satu siklus tanam di Kebun Getas

Figure 3. Rubber productivity in one cycle of life in Getas Estate

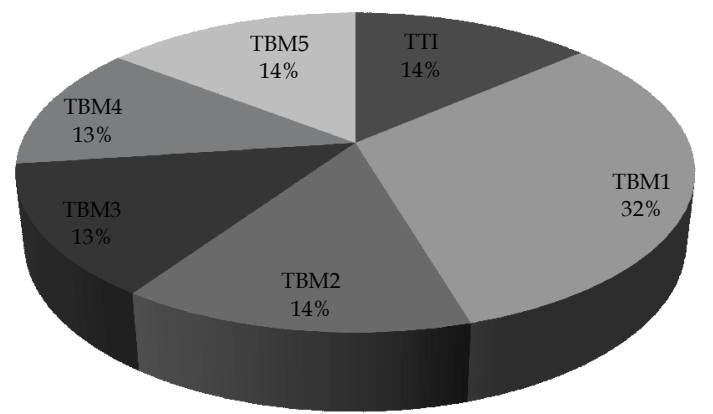

Sumber : PTPN IX, 2013c

Gambar 4. Distribusi biaya investasi tanaman karet per hektar

Figure 4. Distribution of rubber investment cost per hectare

\section{Biaya Produksi}

Biaya produksi merupakan biaya tanaman menghasilkan umur 6-30 tahun (TM 1-25), biaya panen, dan biaya pengolahan karet. Total biaya produksi sejumlah Rp 590.192.000,-/ha. Biaya terbesar adalah untuk biaya pemupukan TM dan pemanenan. Dengan mengkombinasikan data biaya produksi dan produktivitas, diperoleh proyeksi distribusi biaya produksi per hektar per tahun tampak dalam Gambar 5. 


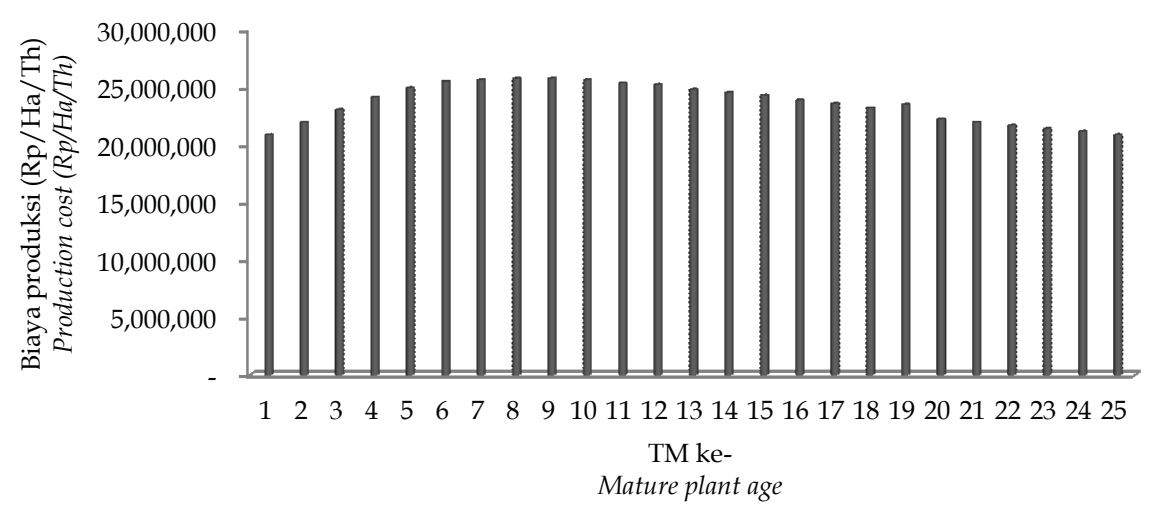

Sumber (source) : PTPN IX, 2013c (data sekunder yang diolah)

Gambar 5. Distribusi biaya produksi karet per hektar per tahun

Figure 5. Distribution of rubber production cost per hectar per years

5. Analisis peremajaan optimal tanaman karet

Hasil penelitian menunjukkan bahwa saat optimal peremajaan adalah 25 tahun, (Gambar 6) dengan menggunakan tingkat bunga riil $4,83 \%$ dan inflasi tahun 2013 sebesar 6,97\%, harga jual karet Rp $27.362 / \mathrm{kg}$ di tingkat Kebun Getas tahun 2013, dan produksi 40 ton dalam satu siklus tanam karet.

Kondisi optimal tercapai pada saat perpotongan antara MNR dengan ANR tertinggi, yaitu tahun ke-25, dimana perusahaan sudah mencapai keuntungan rata-rata tahunan yang maksimum.

6. Pola peremajaan optimal tanaman karet

Hasil perhitungan menggunakan Rumus 3 menunjukkan bahwa pola peremajaan optimal tanaman karet adalah 4\% dari luasan kebun karet. Dengan luas $1.602 \mathrm{Ha}$, maka sebaiknya Kebun Getas melakukan peremajaan seluas 64,08 Ha per tahun nya. Namun, pada tahun 2013, Kebun Getas memiliki luas TTI (Tanaman Tahun Ini) sejumlah $5 \%$, atau lebih besar dari hasil penelitian.

7. Respon peremajaan optimal tanaman karet terhadap perubahan kenaikan biaya dan penurunan harga secara simultan

Respon peremajaan optimal tanaman karet dilakukan terhadap perubahan penurunan harga $5-10 \%$ dan kenaikan biaya $5-10 \%$ secara simultan, menunjukkan hasil yang sama, yaitu saat optimal peremajaan adalah 25 tahun dan pola optimal peremajaan adalah $4 \%$, seperti dalam Tabel 2 .

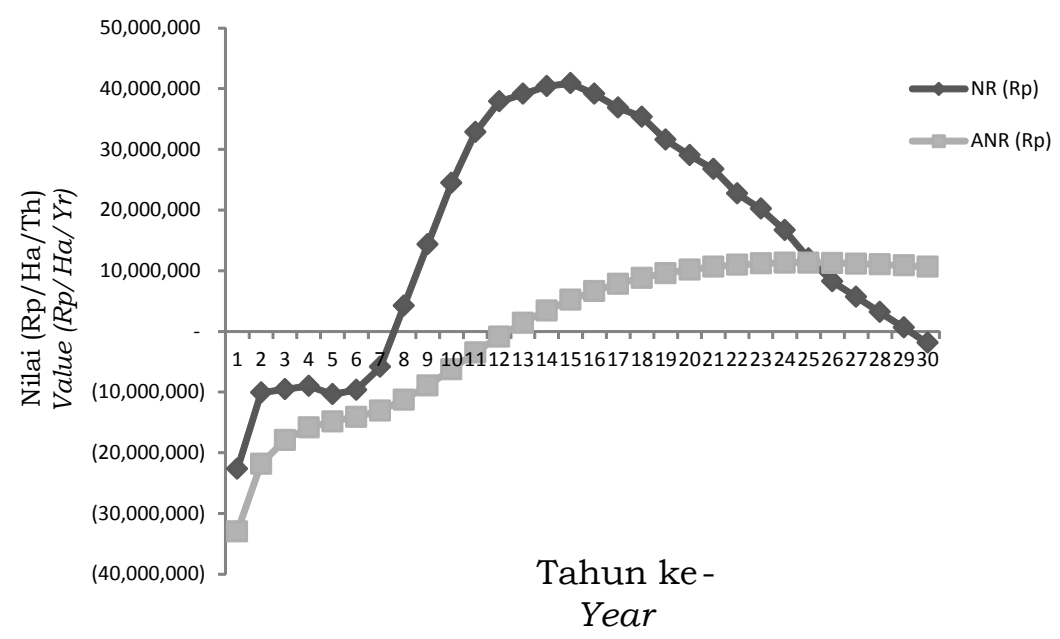

Gambar 6. Saat peremajaan optimal pada saat tahun ke-25

Figure 6. The optimum period to replant rubber at the $25^{\text {th }}$ year 
Tabel 2. Hasil analisis sensitivitas

Table 2. Result of sensitivity analysis

\begin{tabular}{|c|c|c|}
\hline $\begin{array}{l}\text { Kondisi } \\
\text { Condition }\end{array}$ & $\begin{array}{l}\text { Saat optimum } \\
\text { Optimum moment }\end{array}$ & $\begin{array}{l}\text { Pola optimum (\%) } \\
\text { Optimum pattern (\%) }\end{array}$ \\
\hline \multicolumn{3}{|l|}{ Bunga riil 4,83\% } \\
\hline \multicolumn{3}{|l|}{ Real interest $4,83 \%$} \\
\hline Harga Rp $27.362,-$, biaya tetap ...... (1) & 25 & 4 \\
\hline \multicolumn{3}{|l|}{ Price $R p 27.362,-$, the costs is fix } \\
\hline Harga turun $5 \%$, biaya naik $5 \%$..... (2) & 25 & 4 \\
\hline \multicolumn{3}{|l|}{ Price reduced by $5 \%$, the cost rose $5 \%$} \\
\hline Harga turun $6 \%$, biaya naik $6 \%$..... (3) & 25 & 4 \\
\hline \multicolumn{3}{|l|}{ Price reduced by $6 \%$, the cost rose $6 \%$} \\
\hline Harga turun $7 \%$, biaya naik $7 \%$..... (4) & 25 & 4 \\
\hline \multicolumn{3}{|l|}{ Price reduced by $7 \%$, the cost rose $7 \%$} \\
\hline Harga turun $8 \%$, biaya naik $8 \%$..... (5) & 25 & 4 \\
\hline \multicolumn{3}{|l|}{ Price reduced by $8 \%$, the cost rose $8 \%$} \\
\hline Harga turun $9 \%$, biaya naik $9 \%$..... (6) & 25 & 4 \\
\hline \multicolumn{3}{|l|}{ Price reduced by $9 \%$, the cost rose $9 \%$} \\
\hline Harga turun $10 \%$, biaya naik $10 \% \ldots(7)$ & 25 & 4 \\
\hline Price reduced by $10 \%$, the cost rose $10 \%$ & & \\
\hline
\end{tabular}

Meskipun saat dan pola peremajaan optimalnya terjadi pada saat yang sama, namun memiliki perbedaan nilai MNR dan ANR yang semakin rendah seiring dengan turunnya harga dan naiknya biaya, seperti tampak dalam Gambar 7.

Kenyataannya, Kebun Getas akan melakukan peremajaan pada saat umur ekonomis yang bervariasi, yaitu 23-27 tahun (Tabel 3).

Bila dikaitkan dengan hasil penelitian, bilamana perusahaan melakukan peremajaan sebelum 25 tahun, maka perusahaan belum mencapai keuntungan rata-rata tahunan yang maksimum, sedangkan bila diremajakan setelah 25 tahun, maka sudah tidak optimal lagi, karena keuntungan rata-rata tahunannya tidak maksimum lagi, dan justru semakin menurun. Kondisi tersebut, tergantung pada produktivitas tanaman karet, harga jual karet dan biayanya.

Pada umur ke-25, atau TM ke-20 merupakan saat keuntungan rata-rata yag maksimum. Pada saat tersebut, produktivitas sudah menurun, pengurangan dosis pemupukan dan ada juga yang tidak dilakukan pemupukan sama sekali, populasi pohon per hanca sudah jauh berkurang, dan bidang sadap bawah sudah habis sehingga penyadap melakukan sadap

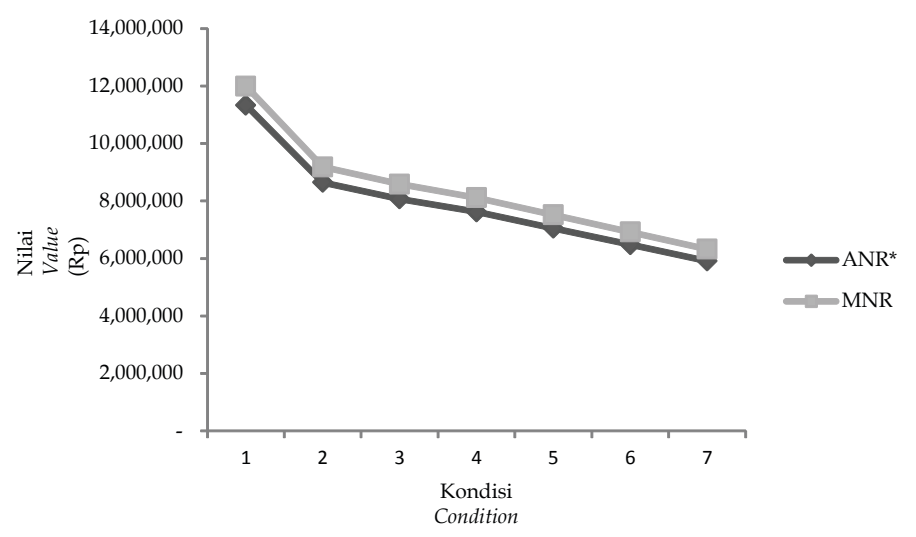

Gambar 7. Nilai ANR* dan MNR yang semakin menurun pada berbagai kondisi

Figure 7. Value of $A N R^{*}$ and MNR that decreases in various conditions 
Tabel 3. Rencana Jangka Panjang di Kebun Getas, 2014-2019

Table 3. Long-Term Plan in Getas Estate, 2014-2019

\begin{tabular}{cccc}
\hline $\begin{array}{c}\text { Tahun Tanam (TT) } \\
\text { Year planted }\end{array}$ & $\begin{array}{c}\text { Tahun Peremajaan } \\
\text { Year of replanting }\end{array}$ & $\begin{array}{c}\text { Umur Tanaman (Th) } \\
\text { Age of trees (years) }\end{array}$ & $\begin{array}{c}\text { Luas (Ha) } \\
\text { Area }(\text { Ha) }\end{array}$ \\
\hline 1988 & 2015 & 27 & 7,73 \\
1989 & 2015 & 26 & 12,04 \\
1991 & 2015 & 24 & 23,7 \\
1993 & 2016 & 23 & 52,95 \\
1990 & 2017 & 27 & 25,56 \\
1995 & 2018 & 23 & 49,13 \\
1995 & 2019 & 24 & 29,68 \\
1996 & 2019 & 23 & 30,11 \\
\hline Rerata (average) & & 24,63 & \\
\hline
\end{tabular}

Sumber (source): PTPN IX, 2014b

atas dengan tingkat kesulitan tinggi dan prestasi yang menurun.

Peremajaan karet memang memerlukan dana yang cukup besar terutama untuk biaya investasi. Biaya investasi tidak dapat ditutup dari hasil pembongkaran kayu tanaman sebelumnya saja, mengingat sebagian besar kayu karet juga dipergunakan sendiri untuk pengasapan di pabrik pengolahan karet, oleh karena itu diperlukan perencanaan keuangan yang tepat dalam perusahaan, agar tidak terkendala dana dalam mengaplikasikan peremajaan pada saat dan pola yang optimal dengan menyisihkan keuntungan yang diperoleh.

\section{KESIMPULAN DAN SARAN}

Hasil analisis penentuan saat optimum peremajaan tanaman karet di Kebun Getas dapat disimpulkan bahwa:

1. Saat optimal peremajaan tanaman karet adalah saat tahun ke-25, dan pola optimum yang tepat adalah 4\% dari luasan lahan.

2. Respon peremajaan optimal terhadap penurunan harga $5-10 \%$ dan kenaikan biaya $5-10 \%$ secara bersamaan, menunjukkan bahwa saat optimal peremajaan tanaman karet tetap di tahun ke-25 dan pola optimum yang tepat di $4 \%$ dari luasan lahan.

3. Sebaiknya perusahaan melaksanakan peremajaan karet dengan pertimbangan teknis dan finansial, sehingga dapat berkelanjutan dan seimbang.

\section{UCAPAN TERIMA KASIH}

Ucapan terimakasih kami sampaikan kepada:

1. Kebun Getas, PT Perkebunan Nusantara IX (Persero) yang telah bersedia menjadi objek penelitian

2. Balai Penelitian Getas, Pusat Penelitian Karet yang sudah mendukung dilaksanakannya penelitian

3. Dr. Ir. Slamet Hartono, MSc, dan Prof. Dr. Ir. Irham, MSc selaku Pembimbing dalam menyusun karya ilmiah ini.

\section{DAFTAR PUSTAKA}

Dillon, J. L. 1968. The Analysis of Response in Crop and Livestock Production. Pergamon Press, Oxford.

Faris, J. E. 1960. Analytical Techniques Used In Determining The Optimum Replacement Pattern. Journal Farming of Economic XLIII (V) : 755756.

Gittinger, J. P. 1986. Analisa Ekonomi Proyek-Proyek Pertanian. Edisi Kedua. UI-Press-Jhon Hopkins, Jakarta.

International Rubber Study Group (IRSG). 2013.International Rubber Study Group. Wembley, London

Iskandar, S. H. 1984. Pengantar Budidaya Karet. Jurusan Agronomi. Fakultas Pertanian. Institut Pertanian Bogor, Bogor 
Jenahar. 2003. Analisis Peremajaan Optimum Karet. Agro Ekonomi 10 (1) : 56-66

Kadariah, L. Karlina, dan C.Gray. 1999. Pengantar Evaluasi Proyek. Edisi Revisi. Lembaga Penerbit Fakultas Ekonomi UI, Jakarta.

Mesike and Sagay. 2010. Optimum Replacement Period for Rubber Plantation in Nigeria. Quarterly Journal of International Agriculture 49 (3) : 257 270.

PTPN IX. 2013a. Laporan Statistik, Kebun Getas Tahun 1999-2013. PT. Perkebunan Nusantara IX, Jawa Tengah.

PTPN IX. 2013b. Laporan Tanaman, Kebun Getas Tahun 1999-2013. PT. Perkebunan Nusantara IX, Jawa Tengah.

PTPN IX. 2013c. Laporan Biaya, Kebun Getas Tahun 2013. PT. Perkebunan Nusantara IX, Jawa Tengah.

PTPN IX. 2014a. Profil PT Perkebunan Nusantara IX (Persero), Kebun Getas Tahun 2014. PT. Perkebunan Nusantara IX, Jawa Tengah.
PTPN IX. 2014b. Rencana Jangka Panjang Tahun 2014-2019 Kebun Getas. PT. Perkebunan Nusantara IX, Jawa Tengah.

Rajino, A. Y. 1984. Pengkajian Biaya dan Manfaat Investasi Modal untuk Peremajaan Tanaman Teh Perkebunan. Disertasi UGM, Yogyakarta.

Sammarappuli, Wickramaratne and Dias, 1997. Economics of Reinvestment on Rubber in The Estate Sector. Journal of Rubber Research Institute of Sri Lanka. 79 : 45-61.

Sutardi. 1973. Metode Ekonomi untuk Menilai Potensi Profitabilitas Tanaman Perkebunan Parenial. Penelitian RRC Getas, Salatiga.

Sutardi. 1973. Teori dan Teknik Penentuan Titik Optimal Peremajaan Tanaman Perkebunan Perenial. Penelitiaan RRC Getas, Salatiga.

Wargadipura, R. 1978. Teknik Penanaman Ulang pada Perkebunan Karet. Menara Perkebunan 46 : 123-130. 